\title{
Review of the literature and individual patients' data meta-analysis on efficacy and tolerance of nitroxoline in the treatment of uncomplicated urinary tract infections
}

Kurt G Naber ${ }^{1 *}$, Hiltrud Niggemann ${ }^{2}$, Gisela Stein ${ }^{3}$ and Guenter Stein ${ }^{4}$

\begin{abstract}
Background: Nitroxoline, a hydroxychinoline derivate, has been used for many years to treat urinary tract infections (UTI). Many uncontrolled, but only few controlled clinical studies have been published. Four so far unpublished, controlled clinical studies were meta-analysed.

Methods: A narrative literature review was performed. In addition the individual patient data (IPD) of 466 females with uncomplicated UTI of four prospective, single blind, randomized, clinical studies with similar protocols using nitroxoline (250 mg tid) versus cotrimoxazole ( $960 \mathrm{mg}$ bid) or norfloxacin (400 mg bid) as controls for 5 days (sporadic UTI) or 10 days (recurrent UTI) were meta-analysed. The primary aim was eradication of bacteriuria 7-13 days after end of therapy (test of cure). Clinical efficacy was determined by elimination of symptoms and safety by adverse events and laboratory tests.

Results: Reviewing a total of 26 uncontrolled, 2 controlled and one postmarketing studies including more than 11,000 patients, good efficacy and safety of nitroxoline could be confirmed. In the four unpublished controlled studies a total of 234 patients were treated orally with nitroxoline and 232 with controls. The safety of nitroxoline was very good and comparable to the controls (adverse events 9.4\% vs 7.8\%; $p=0.360$ ). In the mMITT set (at least one outcome result), in the PP set (test of cure outcome) and in the modified PP set (missing test of cure rated failure) more than $90 \%$ of the patients showed eradication of bacteriuria with nitroxoline, which also met statistical non-inferiority compared to the controls (10\% non-inferiority margin) in all three evaluation sets. The clinical efficacy was similar between the two treatment groups.

Conclusion: The IPD meta-analysis using objective parameters (elimination of bacteriuria) demonstrated equivalent efficacy (non-inferiority) of nitroxoline with the controls tested (cotrimoxazole, norfloxacin) in the treatment of uncomplicated UTI. Considering the good safety and efficacy of nitroxoline as also shown in many uncontrolled and observational studies and the world wide increase of resistance of uropathogens against cotrimoxazole and fluoroquinolones, but not against nitroxoline within the last 20 years, nitroxoline should be reconsidered as one of the first line antibiotics for the treatment of uncomplicated UTI.
\end{abstract}

Keywords: Nitroxoline, Cotrimoxazole, Norfloxacin, Uncomplicated urinary tract infection, Meta-analysis

\footnotetext{
* Correspondence: kurt@nabers.de

${ }^{1}$ Department of Urology, Technical University of Munich, Ismaningerstr. 22,

81675 Munich, Germany

Full list of author information is available at the end of the article
}

C Biomed Central (c) 2014 Naber et al.; licensee BioMed Central Ltd. This is an Open Access article distributed under the terms of the Creative Commons Attribution License (http://creativecommons.org/licenses/by/4.0), which permits unrestricted use, distribution, and reproduction in any medium, provided the original work is properly credited. The Creative Commons Public Domain Dedication waiver (http://creativecommons.org/publicdomain/zero/1.0/) applies to the data made available in this article, unless otherwise stated. 


\section{Background}

Urinary tract infections (UTI) are very frequently found in humans. The most frequent pathogens are Escherichia coli and other species of Enterobacteriaceae. Gram-positive bacteria, such as staphylococci and enterococci, and nonfermenting Gram-negative bacteria, such as Pseudomonas aeruginosa, can also be found [1-4]. Funguria due to Candida spp. is mainly cultured in patients with risk factors, e.g. immunocompromised or with infections due to foreign bodies [5,6]. The worldwide increasing bacterial resistance has become a general therapeutic problem. In many countries the resistance rates of $E$. coli against trimethoprim and cotrimoxazole, have exceeded the $20 \%$ threshold accepted for empiric therapy by far $[1,3,7-9]$. Although in many countries still below $20 \%$, the resistance rates of $E$. coli against fluoroquinolones are also increasing worldwide. Therefore, cotrimoxazole, trimethoprim, fluoroquinolones, the former standard therapeutics for uncomplicated UTI [10], but also amoxicillin with and without clavulanic acid and oral cephalosporins are no more recommended in many of the current guidelines as first line antibiotics for the treatment of uncomplicated UTI (cystitis) [11-13]. Older oral antibiotics, such as fosfomycin trometamol, pivmecillinam, and nitrofurantoin, which have still preserved their antibacterial activity against $E$. coli and other uropathogens, are now mostly recommended as first line antibiotics for this indication [11-13]. But further alternatives should be looked for.

Nitroxoline, 5-nitro-8-hydroxyquinoline, has been described first in the fifties of the last century [14]. Since the sixties it has been used for treatment and prophylaxis of acute and recurrent UTI $[15,16]$ in adults and children in the European countries. Nitroxoline is active against most Gram-negative and -positive uropathogenic bacteria [17-19], against mycoplasmas (M. hominis, Ureaplasma urealyticum) $[20,21]$ and human pathogenic Candida spp [22,23]. The antibacterial activity against Acinetobacter spp., Enterococcus spp., and Serratia spp. is variable and Pseudomonas spp. are considered resistant $[17,19]$. Oral treatment with nitroxoline has no qualitative and quantitative effect on the fecal flora [24].

The rate of susceptibility of $E$. coli, the leading uropathogen, at a MIC of nitroxoline of $\leq 8 \mathrm{mg} / \mathrm{l}$ is practically $100 \%$ and has not changed over the years as shown by a recent in vitro study with 499 strains from patients with community acquired UTI showing $\mathrm{MIC}_{50^{-}}$and $\mathrm{MIC}_{90}$-values of $2 \mathrm{mg} / \mathrm{l}$ and $4 \mathrm{mg} / \mathrm{l}$, respectively. The unimodal MIC distribution indicates that these pathogens are wild types without any acquired resistance [25]. For other uropathogens, such as K. pneumonia, P. mirabilis. P. vulgaris, M. morganii, and S. saprophyticus the $\mathrm{MIC}_{50^{-}}$and $\mathrm{MIC}_{90^{-}}$-values were between 4-8/ 4-8 mg/l with highest MIC of $8 \mathrm{mg} / \mathrm{l}$ [26]. The $\mathrm{MIC}_{90}$ for various Candida spp., such as Candida albicans,
Candida tropicalis, Candida parapsilosis, Candida krusei, Torulopsis (Candida) glabrata, is between 1 and $4 \mathrm{mg} / \mathrm{l}$ nitroxoline [27], which correlate well with other studies [28].

The mode of antibacterial and antifungal action is based on the ability of nitroxoline to chelate with various metallic bivalent cations [29-31]. The antibacterial actvity of nitroxoline is decreased by the presence of $\mathrm{Mn}^{++}$and $\mathrm{Mg}^{++}$, but not $\mathrm{Ca}^{++}$and univalent ions like $\mathrm{Na}^{+}$and $\mathrm{K}^{+}$. The authors assume that magnesium ions stabilizing the lipopolysaccharide (LPS) molecules in the outer bacterial membrane favour the accumulation of nitroxoline in the bacteria, such as $E$. coli. This process is energy independent. Nitroxoline is binding to bacterial surface structures, which probably leads to an interaction between nitroxoline and magnesium ions complexing with LPS phosphate groups $[30,31]$. The bacterial surface becomes hydrophobic as demonstrated for $E$. coli at 1/8 of MIC of nitroxoline and the adherence to catheter surface is decreased [32]. Nitroxoline inhibits rapidly and selectively RNA synthesis in fission yeast by chelation of bivalent cations required for RNA synthesis [33]. Furthermore, subinhibitory concentrations of nitroxoline have a major inhibitory effect on adhesin expression and bacterial attachment [34-36], which may add an important antibacterial mechanism of nitroxoline. Nitroxoline also reduces the formation and induces the dispersal of Pseudomonas aeruginosa biofilms by chelation of iron and zinc [37].

After single oral administration of $200 \mathrm{mg}$ nitroxoline antibacterial urinary activity can be demonstrated by microbiological assays peaking on average between $216 \mathrm{mg} / \mathrm{l}$ and $220 \mathrm{mg} / \mathrm{l}$ during the urine collection periods $1-2$ hours and 3-4 hours [38]. The HPLC concentrations of free nitroxoline, however, were much lower peaking on average between $3.2 \mathrm{mg} / \mathrm{l}$ and $5.8 \mathrm{mg} / \mathrm{l}$ during that periods. The discrepancy between the two assays was explained by antibacterial active metabolites in urine, because nitroxoline is excreted in the urine in unconjugated as well as conjugated (glucuronide, sulfate etc.) forms [38,39]. A recent study showed that after oral administration of $250 \mathrm{mg}$ about $99 \%$ of the excreted nitroxoline was eliminated as metabolites in urine of volunteers, mainly as sulfate and glucuronide, and only $1.0 \%$ as the parent component $[40,41]$. In this study urinary inhibitory and bactericidal concentrations were determined against selected uropathogens, such as E. coli, K. pneumonia, $P$. mirabilis, and S. saprophyticus. In connection with additional urinary bactericidal kinetic studies it was concluded, that nitroxoline exhibits mainly bacteriostatic activity in urine against susceptible strains. Its antibacterial activity is more pronounced in acidic than in alkaline urine.

The aim of this article is to review systematically the available literature on the use of nitroxoline for treatment 
and prevention of UTI and to meta-analyse four prospective, randomized, single-blind, multicenter, comparative studies, so far unpublished, in order to improve the evidence based recommendation to use nitroxoline as one of the first line drugs for the treatment of uncomplicated UTI (cystitis).

\section{Methods}

Literature search

A narrative literature search concerning efficacy and safety of nitroxoline in the treatment of UTI was performed by the manufacturing company (Rosen Pharma, Blieskastel, Germany). A total of 26 uncontrolled studies including 1206 patients (947 adults and 259 children) published between 1962 and 1987, two controlled studies including 148 patients (100 adult and 48 children) and one postmarketing observational study [42] including 9800 patients with uncomplicated and complicated UTI were found (Tables 1, 2, 3 and 4).

\section{IPD Meta-analysis of four clinical studies}

The individual patients' data (IPD) of four prospective, randomized, single-blind, multicenter, comparative studies (data on file, Rosen Pharma $\mathrm{GmbH}$ ), so far unpublished, were available for this IPD meta-analysis. The four studies were performed to renew marketing registration during December 1992 until 1993 in 20 investigational sites. A total of 466 female patients suffering from acute sporadic cystitis or acute episode of recurrent cystitis was included in the four studies (nitroxoline: $\mathrm{n}=234$; norfloxacin: $\mathrm{n}=54$; cotrimoxazole: $n=178$ ). For the meta-analysis the original individual patient's data (IPD) could be analyzed.

The studies were performed in accordance with the declaration of Helsinki updated in Hongkong 1989 [69]. Before start they were voted positively by the Ethical Commissions of the Medical Councils of Saarland for study NWNF \#10 (dated 7 Sept 1992), Bavaria for study NWNF \#11 (dated 20 October 1992, Nr. 92247), Rheinland-Pfalz for study NWNF \#13 (dated 3 November 1992), and Hessen for study NWNF \# 15 (dated 2 November 1992, Nr. 71/92), and the respective countries of Germany

Table 1 Total number ( $n$ ) of published clinical studies on treatment of urogenital infections with nitroxoline as found by the narrative literature search

\begin{tabular}{llll}
\hline Study design & Population & Studies (n) & Patients (n) \\
\hline Uncontrolled & Adults & 15 & 947 \\
Uncontrolled & Children & 11 & 259 \\
Controlled vs. norfloxacin & Adults & 1 & 100 \\
Controlled vs. TMP/SMX & Children & 1 & 48 \\
Observational & Adults & 1 & 9,800 \\
Total & & $\mathbf{2 9}$ & $\mathbf{1 1 , 1 5 4}$ \\
\hline
\end{tabular}

TMP/SMX - trimethoprim/sulfamethoxazole where the studies where performed. A registration in a public trials registry was not required at that time.

\section{Study design}

The four clinical studies were prospective, randomized, single-blind (patient blinded), multicenter, and comparative in parallel groups. The aim of the studies was to compare the efficacy and safety of nitroxoline versus cotrimoxazole and norfloxacin in female patients with acute uncomplicated sporadic cystitis (NWNF 10, 11, 13) or with acute episode of recurrent uncomplicated cystitis (NWNF 15). In Table 5 the main parameters of the design of the four studies are outlined.

\section{Selection of patients}

After medical history including kind and duration of symptoms, pretreatment and concurrent medication, physical examination including body temperature, urinalysis and confirmation of the clinical diagnosis including additional tests needed, eligible patients were informed about aim, performance, possible adverse events and their right to terminate the study without giving any reasons. If written informed consent was documented, patients were included into the study after inclusion and exclusion criteria had been checked.

In three studies (NWNF 10, 11, 13) female patients with clinical signs and symptoms of acute sporadic uncomplicated cystitis and in one study (NWNF 15) those with acute episode of recurrent uncomplicated cystitis were included. In all patients a pretreatment midstream or single catheter urine sample was requested to show pyuria (white blood cells $>5000 / \mathrm{ml}$ ) and bacteriuria with colony forming units (CFU) $\geq 10^{5} / \mathrm{ml}$ due to susceptible pathogens.

According to the study protocol exclusion criteria were: age below 18 years; taking part in a clinical study during the last 30 days; pregnancy; urolithiasis or obstruction within the urinary tract; severe systemic, gastrointestinal, kidney or liver diseases; hypertension; diabetes mellitus; known erythema exsudativum multiforma, pathologic hemogram including hemoglobin anomalies; glucose-6-phosphate-deficiency; acute porphyria; folic acid deficiency; known seizure disorder; and allergy against sulfonyl urea antidiabetics and sulfonamide based diuretics.

\section{Randomization, treatment, and visits}

Female patients were randomized in two age groups (upto 45 and above 45 years) and received their allocated antibiotic wrapped in a neutral box signed "for clinical study only". Because an objective outcome (eradication of bacteriuria) was the primary aim of the study, a double-blind design was not considered necessary at that time. 
Table 2 Fifteen uncontrolled clinical studies with nitroxoline in 947 adult patients of both genders

\begin{tabular}{|c|c|c|c|c|c|c|c|}
\hline First author & Year & Pat (n) & Indication (T/P) & Dosage & Duration & Success rate & Adverse events \\
\hline Kuss [43] & 1962 & 72 & T: acute cUTI \& uUTI & $400 \mathrm{mg} / \mathrm{d}$ & $20-45$ days & $78 \%$ & $1.3 \%$ gastrointestinal \\
\hline Moreau [44] & 1962 & 20 & T: acute CUTI & $400-500 \mathrm{mg} / \mathrm{d}$ & $\begin{array}{l}8-10(-45) \\
\text { days }\end{array}$ & $90 \%$ & $5 \%$ gastrointestinal \\
\hline \multirow[t]{2}{*}{ v. Rütte [45] } & \multirow[t]{2}{*}{1969} & \multirow[t]{2}{*}{200} & \multirow[t]{2}{*}{ P: chronic rUTI } & $300-500$ mg/d & 2-3 months & \multirow[t]{2}{*}{$80 \%$} & \multirow[t]{2}{*}{$0 \%$} \\
\hline & & & & shortly $800 \mathrm{mg} / \mathrm{d}$ & 1 day & & \\
\hline Uhlir [46] & 1972 & 20 & $\begin{array}{l}\text { T: acute UTI (7), chronic } \\
\text { PN (13) }\end{array}$ & $300 \mathrm{mg} / \mathrm{d}$ & 14 days & $100 \%$ & $0 \%$ \\
\hline Allal [47] & 1973 & 264 & T: UTI during pregnancy & $300 \mathrm{mg} / \mathrm{d}$ & 6 days & $>75 \%$ & No data \\
\hline Bittard [48] & 1974 & 50 & P: post-op. catheter & $7.5-10 \mathrm{mg} / \mathrm{kg} / \mathrm{d}$ & 6 weeks & $92 \%$ & Few gastrointestinal \\
\hline Schlesinger [49] & 1975 & 65 & $\begin{array}{l}\text { T: chronic PN (62), chronic } \\
\text { prostatitis (3) }\end{array}$ & $300-500 \mathrm{mg} / \mathrm{d}$ & 10 days & $80 \%$ clinical & $0 \%$ \\
\hline Aubert [50] & 1976 & 28 & $\begin{array}{l}\text { T: post-op. catheter, after } \\
\text { endoscopy }\end{array}$ & $200-300 \mathrm{mg} / \mathrm{d}$ & 10-15 days & $72 \%$ & $0 \%$ \\
\hline Dufour [51] & 1979 & 15 & T: acute prostatitis & $900-1600 \mathrm{mg} / \mathrm{d}$ & $3-5$ days & $81 \%$ & No data \\
\hline Lenzner [52] & 1983 & 60 & T: fungal UTI & $750 \mathrm{mg} / \mathrm{d}$ & 10-20 days & $80 \%$ & $\begin{array}{l}3.3 \% \text { itching; few cases } \\
\text { with nausea and } \\
\text { vomiting }\end{array}$ \\
\hline Schülke [53] & 1984 & 50 & $\begin{array}{l}\text { T: postop., acute UTI after } \\
\text { removal of urethral catheter } \\
\text { for 3-10 days }\end{array}$ & $750 \mathrm{mg} / \mathrm{d}$ & 3 days & $78 \%$ & $0 \%$ \\
\hline Sachse [54] & 1984 & 44 & P: chronic rUTI & $750 \mathrm{mg} / \mathrm{d}$ & 4 months & $\begin{array}{l}77 \% \text { free of rUTl; rUTI } \\
\text { rate decreased from } \\
0.33 \text { to } 0.11 / \text { month }\end{array}$ & $\begin{array}{l}\text { 9\% gastrointestinal } \\
2.2 \% \text { exanthema }\end{array}$ \\
\hline Demontrond [55] & 1986 & 15 & $\begin{array}{l}\text { T: candiduria in hospitalised } \\
\text { patients }\end{array}$ & $600 \mathrm{mg} / \mathrm{d}$ & 10-30 days & $87 \%$ & $0 \%$ \\
\hline \multirow[t]{3}{*}{ Frobert [56] } & \multirow[t]{3}{*}{1987} & \multirow[t]{3}{*}{36} & \multirow{3}{*}{$\begin{array}{l}\text { T: acute, UUTI in hospitalised } \\
\text { patients }\end{array}$} & \multirow[t]{3}{*}{$600 \mathrm{mg} / \mathrm{d}$} & \multirow[t]{3}{*}{10 days } & 93\% bacteriological & $5.5 \%$ gastrointestinal \\
\hline & & & & & & \multirow[t]{2}{*}{$87 \%$ clinical } & $2.7 \%$ nausea \\
\hline & & & & & & & 2.7\% dizziness \\
\hline Cancet [27] & 1987 & 8 & T: urogenital fungal infections & $600 \mathrm{mg} / \mathrm{d}$ & 15 days & $100 \%$ & no data \\
\hline
\end{tabular}

T-therapy; P-prophylaxis; UTI-urinary tract infection; uUTI-uncomplicated UTI; CUTI-complicated UTI; PN-pyelonephritis.

Patients in the nitroxoline group were asked to take one capsule containing $250 \mathrm{mg}$ nitroxoline three times daily with the three main meals. Patients of the control group were asked to take one tablet containing $960 \mathrm{mg}$ cotrimoxazole (NWNF 10, 11, 15) or $400 \mathrm{mg}$ norfloxacin (NWNF 13) twice daily with the morning and evening meal. The treatment duration was 5 days in 3 studies (NWNF 10,11,13) and 10 days in one study (NWNF 15). The control visits were one day (end of treatment) and 7-13 days (test of cure) after end of therapy. In the ten day treatment study (NWNF 15) an additional visit during therapy at day 6 was scheduled.

Primary objectives The primary objective was the eradication (CFU $<10^{4} / \mathrm{ml}$ ) of the bacteriuria due to susceptible pathogens at test of cure in compliant patients $(\geq 80 \%$ of medication) without taking any additional antibiotic.
Secondary objectives Secondary objectives were clinical efficacy and safety. For clinical efficacy the following symptoms were scored (0-absent upto 5-very severe) by the patient: dysuria, frequency, urgency, nycturia, flank/back pain. The clinical efficacy was assessed also globally by the patient and the investigator. At each visit patients were asked for any adverse event, which was documented. The safety was assessed also globally by the patient and the investigator.

The following laboratory tests were performed: Urinalysis (white and red blood cells, nitrite reaction, protein, glucose, $\mathrm{pH}$ ), serum chemistry (glucose, creatinine, bilirubin, AST, ALT, gammaGT, sodium, potassium, calcium) and hematology (red and white blood count, thrombocytes, blood sedimentation rate).

\section{Evaluation sets}

The efficacy and safety was analysed in the following patients' sets: 
Table 3 Eleven uncontrolled clinical studies on treatment and prophylaxis of UTI with nitroxoline in 259 children

\begin{tabular}{|c|c|c|c|c|c|c|c|}
\hline First author & Year & Patients (n) & Indication (T/P) & Dosage & Duration & Success rate & Adverse events \\
\hline \multirow[t]{2}{*}{ Lecornu [57] } & 1974 & 25 children & T: compl. and uncompl. UTI & 50-400 mg/d as suspension & 4-12 days & $72 \%$ & $8 \%$ nausea \\
\hline & & $0-13$ years & & & & & \\
\hline \multirow[t]{2}{*}{ Roussel [58] } & 1974 & 24 children & T: compl. and uncompl. UTI & $10 \mathrm{mg} / \mathrm{kg} / \mathrm{d}$ as suspension & 10 days- 6 months & $79 \%$ & $0 \%$ \\
\hline & & 7 days -6 months & & & & & \\
\hline \multirow[t]{2}{*}{ Raynaud [59] } & 1974 & 19 children & T: compl. and uncompl. UTI & $10 \mathrm{mg} / \mathrm{kg} / \mathrm{d}$ as suspension & 20 days & $69 \%$ & $10 \%$ nausea \\
\hline & & $0-10$ years & & & & & \\
\hline \multirow[t]{2}{*}{ Luckel [60] } & 1975 & 25 children & P: compl. and uncompl. UTI & $10-20 \mathrm{mg} / \mathrm{kg} / \mathrm{d}$ as suspension & 17-55 days & $83 \%$ & $0 \%$ \\
\hline & & $0-8.5$ years & & & & & \\
\hline \multirow[t]{2}{*}{ Viville [61] } & 1975 & 22 children & P: compl. UTI & $10-30 \mathrm{mg} / \mathrm{kg} / \mathrm{d}$ as suspension & $3-6$ months & $86 \%$ & $0 \%$ \\
\hline & & 2 months- 17 years & & & & & \\
\hline \multirow[t]{2}{*}{ Chable [62] } & 1975 & 28 children & T: compl. and uncompl. UTI & $10-20 \mathrm{mg} / \mathrm{kg} / \mathrm{d}$ as suspension & 10 days & $81 \%$ & $0 \%$ \\
\hline & & 2 month- 14.5 years & & & & & \\
\hline \multirow[t]{2}{*}{ Battin [63] } & 1975 & 30 children & P: compl. and uncompl. UTI & $10 \mathrm{mg} / \mathrm{kg} / \mathrm{d}$ as suspension & 6 weeks & $90 \%$ & $0 \%$ \\
\hline & & 2 month-10 years & & & & & \\
\hline \multirow[t]{2}{*}{ Sorez [64] } & 1975 & 30 children & T: compl. and uncompl. UTI & $10-25 \mathrm{mg} / \mathrm{kg} / \mathrm{d}$ as suspension & $10-17$ days & 73.7\% uncompl. UTI 40\% compl. UTI & $0 \%$ \\
\hline & & 10 days -8 years & & & & & \\
\hline \multirow[t]{2}{*}{ Neimann [65] } & 1975 & 21 children & T/P: compl. and uncompl. UTI & 25-400 mg/d as suspension & 4 days- 4 months & $90 \%$ & $10 \%$ nausea \\
\hline & & 26 days -8 years & & & & & \\
\hline \multirow[t]{2}{*}{ Machecourt [66] } & 1976 & 23 children & T: compl. and uncompl. UTI & 10-20 mg/kg/d as suspension & 10 days & $91 \%$ & $0 \%$ \\
\hline & & 21 days- 14 years & & & & & \\
\hline \multirow[t]{2}{*}{ Lambert-Zechovsky [24] } & 1987 & 12 children & T: uncompl. UTI & $20 \mathrm{mg} / \mathrm{kg} / \mathrm{d}$ as suspension & 10 days & 66\% (91\% incl. non-compliance) & - \\
\hline & & aver. 4 years & & & & & \\
\hline
\end{tabular}

n-number; T-therapy; P-prophylaxis; UTI-urinary tract infection. 
Table 4 Two controlled open clinical studies in a total of 148 patients with nitroxoline (NTX) versus norfloxacin (NFX) or cotrimoxazole (CTX); SMX-sulphamethoxazole; TMP-trimethoprim

\begin{tabular}{|c|c|c|c|c|c|c|c|}
\hline First author & Year & Pat.(n) & Indication (T/P) & Antibiotic and dosage & Duration & Success rate & Adverse events \\
\hline \multirow[t]{2}{*}{ Schülke [67] } & \multirow[t]{2}{*}{1986} & 51 NTX & \multirow[t]{2}{*}{ T: postop., uncompl. UTI } & \multirow{2}{*}{$\begin{array}{l}750 \mathrm{mg} \text { NTX/d vs. } 800 \mathrm{mg} \\
\text { NFX/d }\end{array}$} & \multirow[t]{2}{*}{3 days } & \multirow[t]{2}{*}{$60.8 \%$ NTX 59.2\% NFX } & \multirow[t]{2}{*}{$0 \%$} \\
\hline & & $49 \mathrm{NFX}$ & & & & & \\
\hline \multirow[t]{2}{*}{ Dodat [68] } & \multirow[t]{2}{*}{1988} & 48 children & \multirow{2}{*}{$\begin{array}{l}\text { P: postop. UTI } \\
\text { (ureteral reflux) }\end{array}$} & $10 \mathrm{mg} \mathrm{NTX/kg/d}$ & \multirow[t]{2}{*}{ 30-60 days } & $95 \%$ NTX & $6 \%$ NTX \\
\hline & & $0-8$ years & & $\begin{array}{l}\text { vs. } 15 \mathrm{mg} \text { SMX/ } 3 \text { mg } \\
\text { TMP/kg/d }\end{array}$ & & $95 \%$ CTX & $5 \%$ CTX \\
\hline
\end{tabular}

T-therapy; P-prophylaxis, UTI-urinary tract infection.

Safety set: All patients included into the study having received any study medication.

Modified microbiologically Intention-to-Treat Set (mMITT): All patients with significant bacteriuria $\left(\mathrm{CFU} \geq 10^{5} / \mathrm{ml}\right)$ at study entry; with at least one control visit including microbiological investigation, and with a consistent clinical report (in study NWNF 10 few clinical reports were inconsistent). The last observation was brought forward (LOF), if not failure has already been documented and an additional antibiotic been administered.

Per Protocol Set (PP): All patients with significant bacteriuria (CFU $\geq 10^{5} / \mathrm{ml}$ ) at study entry; with test of cure visit including microbiological investigation (except failure was already documented and additional antibiotic administered); doubtless randomization; and compliance ( $\geq 80 \%$ of allocated drug).

Modified per Protocol Set (mPP): All patients with significant bacteriuria (CFU $\geq 10^{5} / \mathrm{ml}$ ) at study entry; with test of cure visit including microbiological investigation; missing test of cure visit was rated as failure (worst case) [70]; doubtless randomization; and compliance ( $\geq 80 \%$ of allocated drug).

\section{Statiscial analysis}

The individual patient data were entered and independently checked to ensure high data quality. Categorial data are described by absolute and relative frequencies. Ordinal data are either described in tables by absolute and relative frequencies (global clinical assessment) or by box plots (scoring of clinical symptoms). For numerical data median as well as minimum and maximum value are given.

To evaluate the noninferiority of nitroxoline compared to the controls with regard to the failure rate the difference of the failure rates of the two treatments and its 95\%-confidence interval is estimated [71]. Odds Ratios are estimated, too. Difference as well as odds ratio are estimated by logistic regression with random center effect [72]. Since the proportion of variance explained by the centers exceeded substantially the proportion of variance explained by the four studies random center effects instead of random study effects were added to the model. Wether the distribution of ordinal data is the same in the two treatment groups is analyzed by ordered probit regression, the distribution of numerical data is compared by linear regression. For both approaches random center effects are taken into account.

Table 5 Study design of the four meta-analysed prospective, open, randomised clinical studies in female patients with acute uncomplicated and recurrent cystitis treated with nitroxoline (NTX) versus a control antibiotic, cotrimoxazole (CTX) or norfloxacin (NFX)

\begin{tabular}{|c|c|c|c|c|c|c|c|}
\hline Study & Nitroxoline & Control & Indication & Patients (n) & Duration & $\begin{array}{l}\text { End of therapy } \\
\text { visit }\end{array}$ & $\begin{array}{l}\text { Test of cure } \\
\text { visit }\end{array}$ \\
\hline \multirow[t]{2}{*}{ NWNF $10^{\circ}$} & Nitroxoline (NTX) & Cotrimoxazole (CTX) & Acute uncompl. cystitis & 130 total & 5 days & day 6 & day $12-14$ \\
\hline & $3 \times 250 \mathrm{mg}$ & $2 \times 960 \mathrm{mg}$ & & 67 NTX, 63 CTX & & & \\
\hline \multirow[t]{3}{*}{ NWNF 11} & Nitroxoline (NTX) & Cotrimoxazole (CTX) & Acute uncompl. cystitis & 115 total & 5 days & day 6 & day $12-14$ \\
\hline & $3 \times 250 \mathrm{mg}$ & $2 \times 960 \mathrm{mg}$ & & 56 NTX & & & \\
\hline & & & & 59 CTX & & & \\
\hline \multirow[t]{3}{*}{ NWNF 13} & Nitroxoline (NTX) & Norfloxacin (NFX) & Acute uncompl. cystitis & 105 total & 5 days & day 6 & day $12-14$ \\
\hline & $3 \times 250 \mathrm{mg}$ & $2 \times 400 \mathrm{mg}$ & & 51 NTX & & & \\
\hline & & & & $54 \mathrm{NFX}$ & & & \\
\hline \multirow[t]{3}{*}{ NWNF 15} & Nitroxoline (NTX) & Cotrimoxazole (CTX) & Acute episode of uncompl. & 116 total & 10 days & day $11-13^{*}$ & day $21-23$ \\
\hline & $3 \times 250 \mathrm{mg}$ & $2 \times 960 \mathrm{mg}$ & & 60 NTX & & & \\
\hline & & & & 56 CTX & & & \\
\hline
\end{tabular}


All p-values are two-sided, the level of significance is set to 0.05 . Stata/IC 13.1 was used for data preparation and statisical analysis.

\section{Results}

Literature search

The 26 uncontrolled clinical studies published between 1962 and 1987 included a total of 1206 patients (947 adults and 259 children) (Table 1 ). Nitroxoline was mainly administered for treatment of uncomplicated and complicated UTI as well as for prophylaxis of recurrent UTI with daily dosages mostly between 300 and $900 \mathrm{mg}$. The treatment duration varied mainly between 3 and 10 days depending on the indication. Study details are presented in Tables 2 and 3.

The summary results of the two controlled studies including 148 patients (100 adult and 48 children) are outlined in Table 4. In one study 51 patients received $250 \mathrm{mg}$ nitroxoline tid versus 49 patients $400 \mathrm{mg}$ norfloxacin bid for treatment of postoperative and uncomplicated UTI [67]. The microbiological outcome was comparable in both groups (about 60\%); no adverse events were reported. The second controlled study was performed in 48 children with ureteral reflux [68]. The children received either nitroxoline or cotrimoxazole for prophylaxis of UTI for 30-60 days. In 95\% of the children a recurrent UTI could be prevented in both groups. Adverse reactions were reported in $6 \%$ with nitroxoline and in $5 \%$ with cotrimoxazole.

The postmarketing observational study included 9800 patients (75\% women, $25 \%$ men) with complicated and uncomplicated UTI including recurrent UTI, and to a lesser extent also with fungal urogenital infections [42]. The dosage of nitroxoline was fixed at $250 \mathrm{mg}$ tid, but the treatment duration was chosen according to the physician's decision. The physician's assessment revealed clinical success of 95\% in cystitis, 79\% in recurrent and complicated UTI; $80 \%$ in pyelonephritis, and $91 \%$ in fungal infections. The overall patient's assessment of success was $95 \%$. Only $2.2 \%$ of the patients reported adverse events overall including $1.8 \%$ gastrointestinal and $0.3 \%$ allergic adverse events.

\section{IPD meta-analysis Patients}

The studies were performed in 20 German cites from Dezember 1992 until 1993. A total of 466 female patients (nitroxoline: $\mathrm{n}=234$, controls: norfloxacin: $\mathrm{n}=54$; cotrimozazole: $n=178$ ) was included in the four clinical studies. In the IPD meta-analysis the results obtained from patients in the nitroxoline group were compared with those obtained from patients in the control groups, norfloxacin and cotrimoxazole.

\section{Demography, history and physical examination}

In Table 6 some data concerning demography, history and physical examination are compared between nitroxoline and controls in the safety set. A significant difference was only found as a slightly higher body mass index, higher systolic blood pressure and a lower proportion pretreated by antibiotics in the group of the controls. Both groups included about the same number of patients upto 45 and above 45 years. Although diabetes mellitus and hypertension, considered as exclusion criteria in the original protocol, was found in some patients in both groups, these patients were not excluded from the meta-analysis, because these underlying diseases were considered only minor protocol violations.

\section{Flow of patients}

In Figure 1 the total number of patients included in the studies is shown, randomized to nitroxoline and controls and excluded because of different reasons from the evaluation sets. Finally the safety (mMITT/mPP/PP) set comprised 234 (211/205/200) patients in the nitroxoline and $232(213 / 210 / 206)$ in the control groups.

\section{Quality of the studies}

Each of the four randomized clinical trials achieved a good quality with four out of maximum five Jadad scores [73,74]: randomization (1 score), which was appropriate (1 score), patient blinding only (0 score), which was appropriate (1 score), and drop-outs well-grounded (1 score).

\section{Bacterial spectrum and resistance to study drugs}

The bacterial spectrum and resistance at study entry (visit 1) is shown in Table 7 . On average about $10 \%$ of the patients were included with mixed infections. Therefore the total number of isolates were higher than the number of patients included. Escherichia coli was the most frequent pathogen in all studies ranging from $65 \%$ to $73 \%$ of all isolates. The percentages of resistant isolated to nitroxoline ranged from $0 \%$ to $5.5 \%$ and that to the control antibiotics from $0.8 \%$ to $5.2 \%$. There was no evidence, that patients with recurrent UTI (study NWNF 15) showed more resistant strains than patients with sporadic UTI (studies NWNF 10,11,13).

\section{Microbiological outcome}

The micobiological outcome (eradication of bacteriuria $<10^{4} / \mathrm{ml}$ ) as primary study aim is shown in Table 8 . In all three evaluation sets the eradication rates were above $90 \%$ in the nitroxoline and in the control groups. The $95 \%$ confidence intervals $(\mathrm{CI})$ of the estimated eradication rate differences met statistical non-inferiority compared to the controls (10\% non-inferiority margin) in all three evaluation sets.

Figure 2 shows the 95\% CI of the individual studies and the total result of the four meta-analysed studies 
Table 6 Demography, history, and physical parameters of female patients investigated in the safety set

\begin{tabular}{|c|c|c|c|c|c|}
\hline \multirow[b]{2}{*}{ Demographic parameter } & \multicolumn{2}{|c|}{ Nitroxoline } & \multicolumn{2}{|c|}{ Controls } & \multirow[t]{2}{*}{ p-value } \\
\hline & $n$ & Median (range) & $\mathbf{n}$ & Median (range) & \\
\hline Age (years) & 234 & $48(18-89)$ & 232 & $47(18-85)$ & 0.520 \\
\hline -up to 45 years & 234 & $113(48.3 \%)$ & 232 & $115(49.6 \%)$ & 0.745 \\
\hline Height (cm) & 234 & $165(150-185)$ & 231 & $165(145-187)$ & 0.290 \\
\hline Weight (kg) & 234 & $62(43-100)$ & 232 & $64(42-102)$ & 0.125 \\
\hline Body mass index $\left(\mathrm{kg} / \mathrm{m}^{2}\right)$ & 234 & $23.0(15.9-41.3)$ & 231 & $23.2(15.6-38.0)$ & 0.038 \\
\hline Heart rate $\left(\min ^{-1}\right)$ & 231 & $80(52-172)$ & 231 & $80(56-120)$ & 0.354 \\
\hline Systolic BP (mmHg) & 232 & $120(80-195)$ & 231 & $130(100-190)$ & 0.025 \\
\hline Diastolic BP (mmHg) & 232 & $80(60-120)$ & 231 & $80(50-120)$ & 0.410 \\
\hline No hypertension (SBP $\leq 140$ mmHG) & 232 & $165(71.1 \%)$ & 231 & $137(59.3 \%)$ & 0.004 \\
\hline Mild hypertension (SBP > 140 mmHG) & 232 & $46(19.8 \%)$ & 231 & $63(27.3 \%)$ & \\
\hline Moderate hypertension (SBP > 160 mmHG) & 232 & $17(7.3 \%)$ & 231 & $22(9.5 \%)$ & \\
\hline Severe hypertension (SBP > 180 mmHG) & 232 & $4(1.7 \%)$ & 231 & $9(3.9 \%)$ & \\
\hline Diabetes mellitus & 234 & $11(4.7 \%)$ & 232 & $6(2.6 \%)$ & 0.230 \\
\hline Duration of urinary symptoms (d) & 165 & $3(1-30)$ & 168 & $3(1-21)$ & 0.442 \\
\hline Pretreatment with antimicrobials* & 234 & $16(6.8 \%)$ & 232 & $8(3.4 \%)$ & 0.060 \\
\hline Only unspecific pretreatment ${ }^{\#}$ & 234 & $25(10.7 \%)$ & 232 & $28(12.1 \%)$ & 0.667 \\
\hline
\end{tabular}

*antibiotics, chemotherapeutics.

\#spasmolytics, analgetics, tea etc.

together in the mMITT and the PP sets with the contributing weight of each study.

The eradication rates of E. coli in mono and mixed infection and Non-E. coli mono and mixed infections in the PP set are shown in Table 9. As expected about $80 \%$

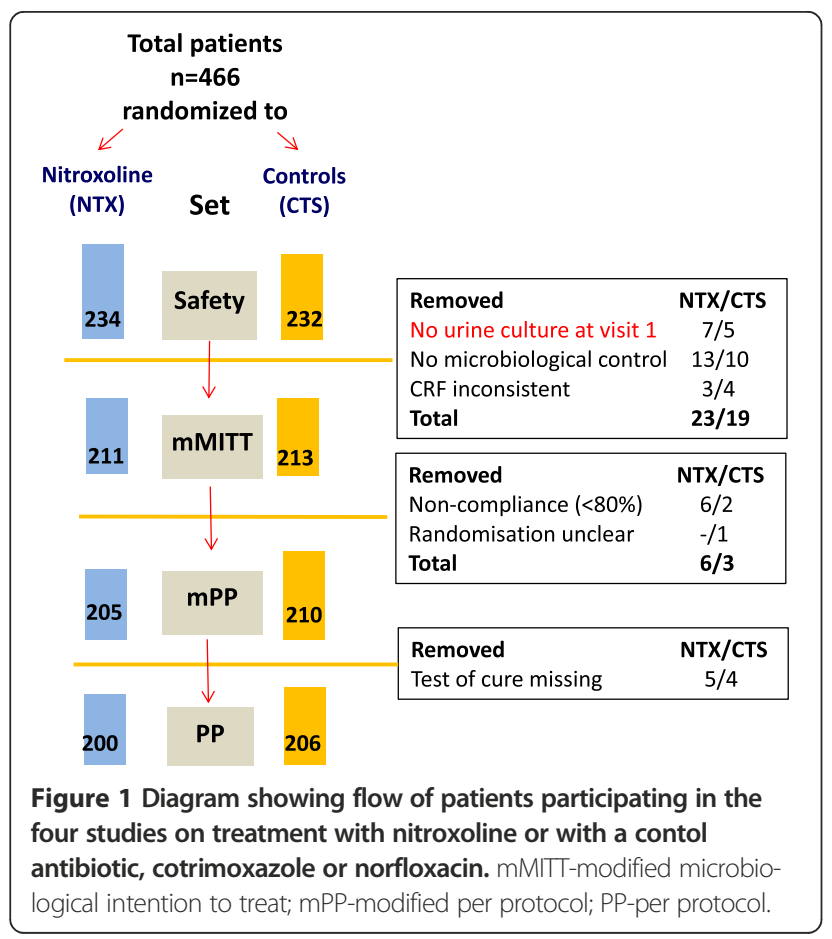

(79.0\% vs $79.6 \%)$ of the patients in both groups had an E. coli infection either as mono or mixed infection with overall eradication rates of $94.3 \%$ and $96.3 \%$, respectively. In the about $20 \%$ Non- $E$. coli infections the overall eradication was $83.3 \%$ and $93.0 \%$ in the nitroxoline and the control groups, respectively.

\section{Clinical efficacy}

In Figure 3 the clinical efficacy in the PP sets are presented as reduction of symptoms as scored pre- and posttreatment. At the end of therapy no significant differences were seen in dysuria (pain during micturition), nocturia and flank/back pain between the two groups. Marked reductions of frequency (pollakisuria) and urgency (imperative micturition) were also seen (included) in both groups, which were, however, more pronounced in the controls. Considering the overall low scores achieved at the end of therapy, the differences may not be clinical relevant.

\section{Global clinical assessment}

In the global clinical assessment (Table 10) the patient (investigator) rated the treatment with nitroxoline in 91.2\% (90.5\%) and that with the control antibiotics in $96.2 \%$ $(95.5 \%)$ as very good or good.

\section{Safety}

The treatments with nitroxoline and the control antibiotics were generally well tolerated (Table 11). A total of $9.8 \%$ treated with nitroxoline and $7.8 \%$ treated with a control 
Table 7 Bacterial spectrum and resistance (R) against nitroxoline (Ni) versus controls (C), cotrimoxazole or norfloxacin, at study entry (visit 1)

\begin{tabular}{|c|c|c|c|c|c|c|c|c|c|c|c|c|}
\hline Study Nr./R & $\begin{array}{l}\text { NWNF } \\
10\end{array}$ & $R(n)$ & $\begin{array}{l}\text { NWNF } \\
11\end{array}$ & $R(n)$ & $\begin{array}{l}\text { NWNF } \\
13\end{array}$ & $R(n)$ & $\begin{array}{l}\text { NWNF } \\
15\end{array}$ & $R(n)$ & NWNF 10-13 & $R(n)$ & NWNF 10-15 & $R(n)$ \\
\hline $\begin{array}{l}\text { Bacterial } \\
\text { isolates }\end{array}$ & n (\%) & $\mathrm{Ni} / \mathrm{C}$ & n (\%) & $\mathrm{Ni} / \mathrm{C}$ & n (\%) & $\mathrm{Ni} / \mathrm{C}$ & n (\%) & $\mathrm{Ni} / \mathrm{C}$ & n (\%) & $\mathrm{Ni} / \mathrm{C}$ & n (\%) & $\mathrm{Ni} / \mathrm{C}$ \\
\hline E. coli & $82(67.2 \%)$ & $-/ 1$ & $88(65.3 \%)$ & $1 / 6$ & $81(67.0 \%)$ & $-/-$ & 98(73.0\%) & $-/-$ & $251(66.4 \%)$ & $1 / 7$ & $349(68.2 \%)$ & $1 / 7$ \\
\hline Proteus spp.* & $20(16.4 \%)$ & $-/-$ & $9(6.7 \%)$ & $-/-$ & $8(6.6 \%)$ & $-/-$ & $12(9.0 \%)$ & $-/-$ & $37(9.8 \%)$ & $-/-$ & 49(9.6\%) & $-/-$ \\
\hline Klebsiella spp. & $1(0.8 \%)$ & $-1-$ & $5(3.7 \%)$ & $-/-$ & $1(0.8 \%)$ & $-/-$ & $6(4.5 \%)$ & $-/-$ & $7(1.9 \%)$ & $-1-$ & $13(2.5 \%)$ & $-/-$ \\
\hline Enterobacter spp. & - & - & $2(1.5 \%)$ & $-/-$ & $3(2.5 \%)$ & $-/-$ & $7(5.2 \%)$ & $-/ 2$ & $5(1.3 \%)$ & $-/-$ & $12(2.3 \%)$ & $-/ 2$ \\
\hline Citrobacter spp. & $2(1.6 \%)$ & $-/-$ & - & $-/-$ & $1(0.8 \%)$ & $-/-$ & $1(0.8 \%)$ & $-/-$ & $3(0.8 \%)$ & $-/-$ & $4(0.8 \%)$ & $-/-$ \\
\hline Enterococci & $9(7.4 \%)$ & $-/-$ & 13(9.7\%) & $6 / 1$ & 13(10.7\%) & $-/ 1$ & $2(1.5 \%)$ & $-/-$ & $35(9.3 \%)$ & $6 / 2$ & $37(7.2 \%)$ & $6 / 2$ \\
\hline Staphylococci & $5(4.1 \%)$ & $-/-$ & $7(5.2 \%)$ & $-/-$ & 13(10.7\%) & $1 /-$ & $8(6.0 \%)$ & $-1-$ & $25(6.6 \%)$ & $1 /-$ & $33(6.4 \%)$ & $1 /-$ \\
\hline Streptococci & $2(1.6 \%)$ & $-/-$ & $2(1.5 \%)$ & $-/-$ & $1(0.8 \%)$ & $-/-$ & - & $-/-$ & $5(1.3 \%)$ & $-/-$ & $5(1.0 \%)$ & $-/-$ \\
\hline Others & $1(0.8 \%)$ & $-1-$ & $9(6.7 \%)$ & $-/-$ & - & $-/-$ & - & $-/-$ & $10(2.6 \%)$ & $-/-$ & $10(2.0 \%)$ & $-/-$ \\
\hline \multirow[t]{2}{*}{ Total } & $\begin{array}{l}122 \\
(100 \%)\end{array}$ & $-/ 1$ & $\begin{array}{l}135 \\
(100 \%)\end{array}$ & $7 / 7$ & $\begin{array}{l}121 \\
(100 \%)\end{array}$ & $1 / 1$ & $\begin{array}{l}134 \\
(100 \%)\end{array}$ & $-/ 2$ & $378(100 \%)$ & $8 / 9$ & $512(100 \%)$ & $8 / 11$ \\
\hline & & $-/ 0.8 \%$ & & $5.2 / 5.2 \%$ & & $0.8 / 0.8 \%$ & & $-/ 1.5 \%$ & & $2.1 / 2.4 \%$ & & $1.6 / 2.1 \%$ \\
\hline \multirow[t]{2}{*}{ Isolates/patients } & $122 / 122$ & & $135 / 115$ & & $121 / 105$ & & $134 / 116$ & & $378 / 350$ & & $512 / 466$ & \\
\hline & $(1.0)$ & & $(1.17)$ & & $(1.15)$ & & $(1.16)$ & & $(1.08)$ & & (1.1) & \\
\hline
\end{tabular}

*indol positive and negative strains.

antibiotic reported any adverse event $(\mathrm{p}=0.360)$. Only 5 (nitroxoline 3; controls 2) patients discontinued the treatment prematurely because of adverse events. The main adverse events were gastrointestinal disorders (nitroxoline 19; controls 9). In 3 patients of each group allergic reactions including itching, urticaria and in one case with papules/pustules (nitroxoline) were seen.

In the laboratory parameters (Table 12) no significant differences between critical values were observed between the two treatment groups (nitroxoline/controls), except a higher pretreatment $(12.8 \%$ vs. $6.4 \%)$, but not posttreatment rate of critical values regarding the number of blood erythrocytes in the nitroxoline group.

\section{Discussion}

When nitroxoline was first marketed in the European Union in 1962 for treatment and prophylaxis of UTI, microbiological and observational studies were considered sufficient. For this reason between 1962 and 1987 only uncontrolled studies were published not only for treatment and prophylaxis of uncomplicated, but also for treatment of complicated UTI including pyelonephritis, prostatitis and fungal infections in adults of both genders, and also in children. Only two prospective randomized studies, one for treatment of uncomplicated UTI in adults and one for prophylaxis of UTI in children, were published, both with low number of patients $[67,68]$. Although these studies may not be considered highly evidential, they can at least contribute to establish the safety of nitroxoline in adults as well as in children together with the large postmarketing observational study.

When the requirements became more stringent for the renewal of the regulatory approval, finally achieved in Germany in 2005, four prospective randomized single blind studies were performed during 1992 and 1993 with cotrimoxazole and norfloxacin as controls. All four studies followed in essence the same protocol with the only difference that the treatment duration in women with sporadic uncomplicated UTI was five days and in women with acute episode of recurrent

Table 8 Microbiological success (eradication of bacteriuria) in the different evaluation sets

\begin{tabular}{lllll}
\hline Evaluation set & Nitroxoline & Controls & Difference (\%) (95\%-Cl) & Odds ratio (95\%-Cl) \\
\hline mMITT & $192 / 211(91.0 \%)$ & $203 / 213(95.3 \%)$ & $-3.4(-9.7$ to 3.0) & $0.47(0.21$ to 1.06$)$ \\
PP & $184 / 200(92.0 \%)$ & $197 / 206(95.6 \%)$ & $-2.2(-8.2$ to 3.7) & $0.47(0.19$ to 1.14$)$ \\
mPP & $185 / 205(90.2 \%)$ & $197 / 210(93.8 \%)$ & $-2.9(-9.9$ to 4.1) & $0.60(0.28$ to 1.27$)$
\end{tabular}

mMITT-modified microbiological intention to treat; PP-per protocol; mPP-modified per protocol.

Difference: nitroxoline - controls.

Odds Ratio: nitroxoline vs controls.

Estimation by logistic regression with random center effect. 

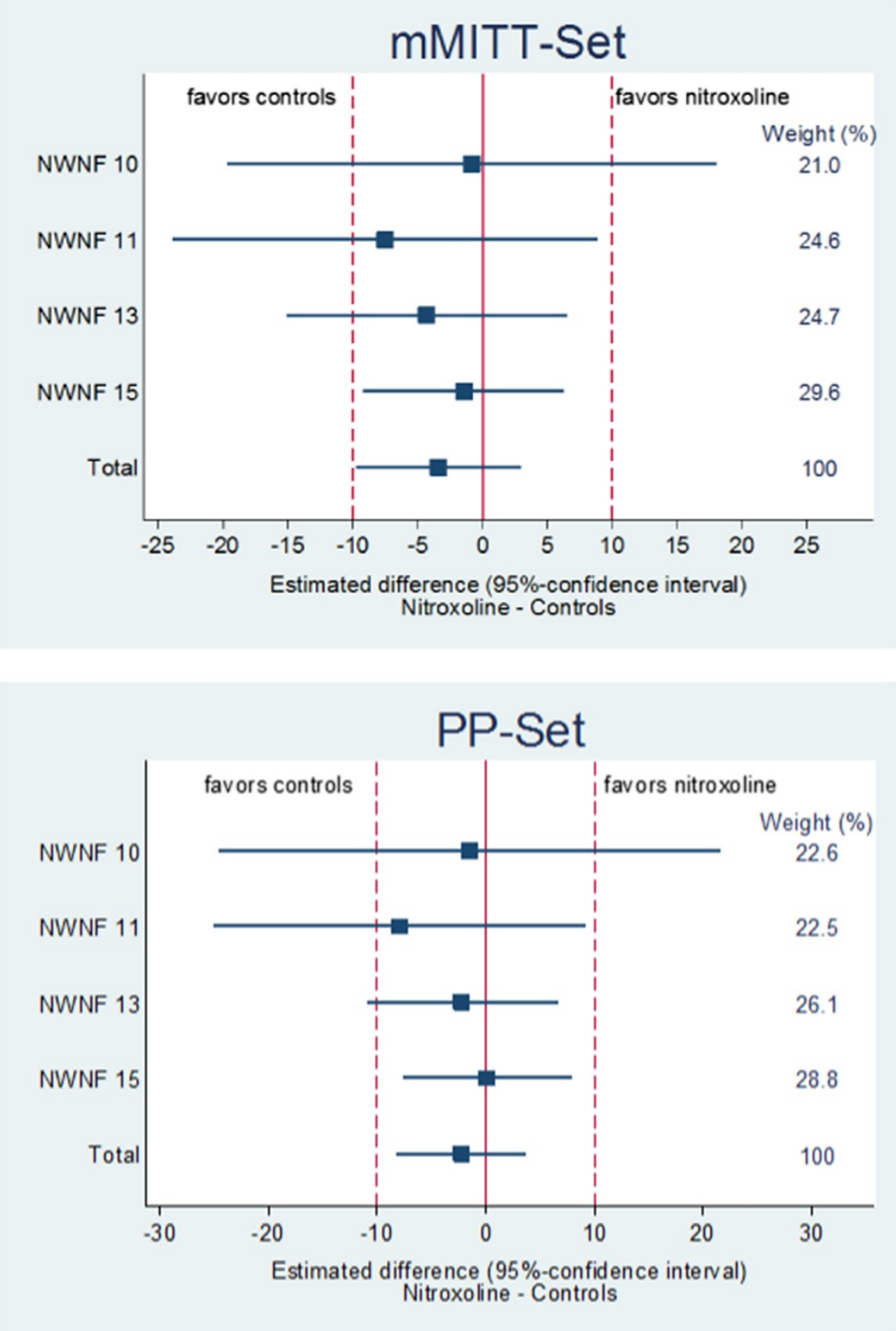

Figure 2 Estimated difference (95\%-confidence interval) between the microbiological success and weights from random effects analysis in the mMITT-Set and PP-Set of patients treated with nitroxoline as compared to controls in the four studies analysed. mMITT-modified microbiological intention to treat; PP-per protocol.

UTI was ten days. All four studies were of high quality achieving four out of maximum five Jadad scores [73,74]. The bacterial spectra were similar between the studies with $E$. coli as most frequent pathogen ranging from $65 \%$ to $73 \%$. There was no evidence that females suffering from recurrent UTI showed more resistant strains than those with sporadic UTI. During the years 1992-1993, when the studies were performed, the resistance rates for cotrimoxazole and norfloxacin were still very low. Both antibiotics were considered first 
Table 9 Microbiological success (eradication of bacteriuria) according to bacterial groups in the PP set

\begin{tabular}{lll}
\hline & Nitroxoline & Controls \\
\hline Monoinfection E. coli & $129 / 138(93.5 \%)$ & $141 / 145(97.2 \%)$ \\
Mixed infection E. coli & $20 / 20(100 \%)$ & $17 / 19(89.5 \%)$ \\
Monoinfection with Non-E. coli & $28 / 34(82.4 \%)$ & $37 / 40(92.5 \%)$ \\
Mixed infection with Non-E. coli & $7 / 8(87.5 \%)$ & $2 / 2(100 \%)$ \\
Total & $184 / 200(92.0 \%)$ & $197 / 206(95.6 \%)$ \\
\hline
\end{tabular}

line drugs for the treatment of uncomplicated UTI at that time [10]. For all these reasons, including the data of all four studies in one meta-analysis was justified.

Since the clinical report forms (CRF) of the individual patients were available, an IPD meta-analysis could be performed, a specific type of systematic review [75]. Rather than extracting summary (aggregate) data from study publications, the original research data are sought directly for each study. These data can then be re-analysed centrally and combined, if appropriate, in meta-analyses. IPD meta-analyses can improve the quality of data and their analysis and thus produce more reliable results [76]. For this reason they are considered a 'gold standard' of systematic review in contrast to meta-analyses of aggregate data, which relates to information averaged or estimated across all individuals in a study. In a two step approach the individual participant data are first analysed in each separate study independently and then synthesized using a suitable model for meta-analysis of aggregate data. With individual participant data an analytic standardisation across the studies and a direct derivation of the information requested is possible, independent of significance or how it was reported.

Since at that time the microbiological evaluation was the primary aim practically in all UTI studies, a singleblind design was considered sufficient, because the eradication (primary aim) could be determined in an objective manner. Nevertheless, from todays point of view the single-blind design could be considered as a weakness of the studies, which may have affected mainly the clinical outcome and some subjective adverse events. However, the non-inferiority of nitroxoline for the eradication of bacteriuria as compared to the controls, cotrimoxazole and norfloxacin, is fairly well established by this IPD meta-analysis, whereas the individual studies contributed each between about 20 and $30 \%$ to the final results. Another shortcoming of the study may be, that after the test of cure the patients were not followed for a longer time. Therefore no information is available concerning the relapse rate after the test of cure visit.

Since the final microbiological evaluation in UTI studies is usually not performed at the end of treatment, but rather after the antibiotic substances are completely
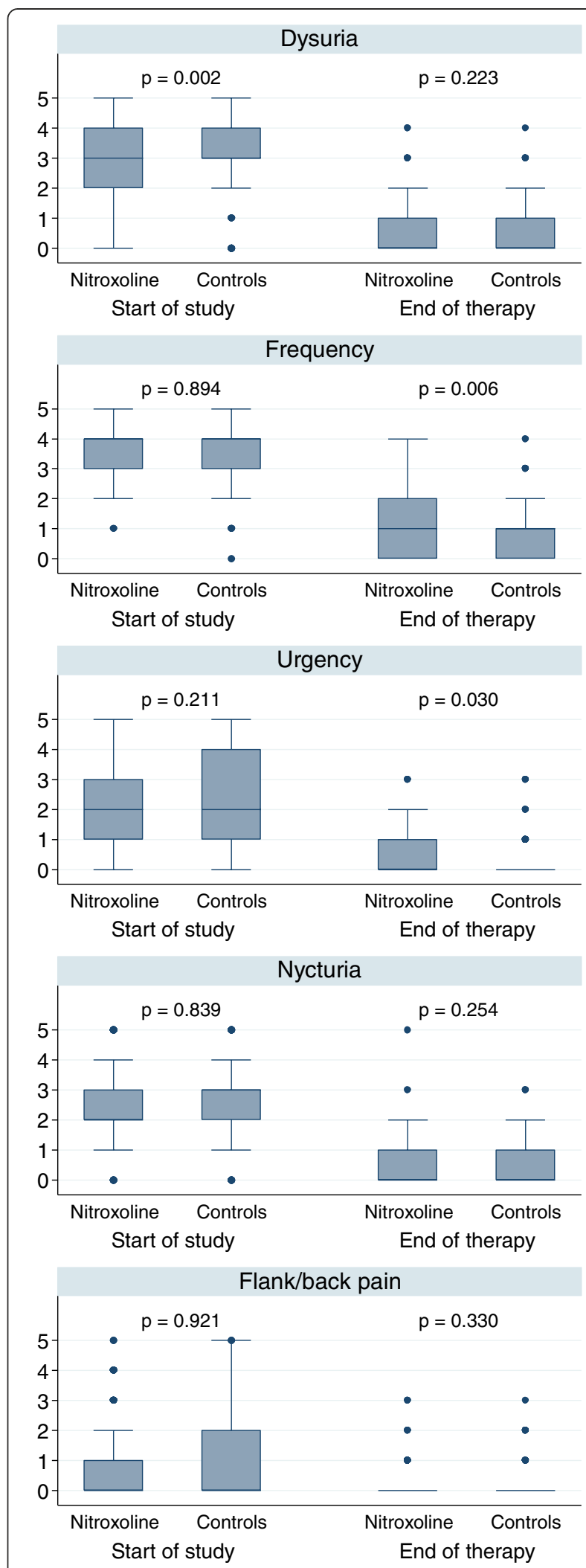

Figure 3 Clinical efficacy (symptom scoring) in the PP treated by nitroxoline $(n=193)$ and the controls $(n=203)$ (no assessment in 10 patients). 
Table 10 Global clinical assessment by the investigator in the PP set (no assessment in 103 patients)

\begin{tabular}{|c|c|c|c|c|}
\hline \multirow{2}{*}{$\begin{array}{l}\text { Assessment } \\
\text { Group }\end{array}$} & \multicolumn{2}{|l|}{ Investigator } & \multicolumn{2}{|l|}{ Patient } \\
\hline & Nitroxoline $(n=148)$ & Controls $(n=158)$ & Nitroxoline $(n=148)$ & Controls $(n=158)$ \\
\hline Very good & $115(77.7 \%)$ & $138(87.3 \%)$ & $109(73.6 \%)$ & $123(77.8 \%)$ \\
\hline Good & 19 (12.8\%) & $13(8.2 \%)$ & $26(17.6 \%)$ & 29 (18.4\%) \\
\hline Satisfactory & $4(2.7 \%)$ & $5(3.2 \%)$ & $5(3.4 \%)$ & $4(2.5 \%)$ \\
\hline Moderate & $1(0.7 \%)$ & $0(0 \%)$ & $3(2.0 \%)$ & $1(0.6 \%)$ \\
\hline Insufficient & $9(6.1 \%)$ & $2(1.3 \%)$ & $5(3.4 \%)$ & $1(0.6 \%)$ \\
\hline$p$-value ${ }^{*}$ & 0.006 & & 0.143 & \\
\hline
\end{tabular}

*comparison of nitroxoline vs. controls (ordered probit regression with random center effect).

eliminated from the urinary tract and uropathogens, still present, have had time to multiply to significant numbers, the usual ITT and PP analyses may benefit good results, when patients drop out with favourable results after the end of treatment visit. These patients are considered a microbiological cure in the ITT set (last observation brought forward) and are drop outs for the classical PP analysis. Thus, possible treatment failures will be not recorded, because usually the reasons for dropping out after the treatment visit remains unknown. Therefore,

Table 11 Adverse events

\begin{tabular}{|c|c|c|c|}
\hline Adverse events (AE) & & Nitroxoline & Controls \\
\hline & Patients (total) & $234(100 \%)$ & $232(100 \%)$ \\
\hline & Patients with $\mathrm{AEs}^{\#}$ & $23(9.8 \%)$ & $18(7.8 \%)$ \\
\hline Adverse events (total) & & 33 & 26 \\
\hline \multirow[t]{2}{*}{ Nervous system disorders } & Headache & 3 & 4 \\
\hline & Dizziness & - & 3 \\
\hline Eye disorders & Eyelid swelling & 1 & - \\
\hline Cardiac and circulation disorders & Circulation disorder & - & 1 \\
\hline \multirow[t]{6}{*}{ Gastrointestinal disorders } & Dysgeusia & - & 1 \\
\hline & Nausea & 9 & 3 \\
\hline & Regurgitation & 1 & 1 \\
\hline & Gastralgia & 4 & 3 \\
\hline & Obstipation & - & 1 \\
\hline & Diarrhoea & 5 & - \\
\hline Metabolim and nutrition disorder & Anorexia & 1 & - \\
\hline Urinary disorders & Incontinence & 1 & - \\
\hline \multirow[t]{3}{*}{ Reproductive system disorders } & Colpitis & 1 & 1 \\
\hline & Fluor vaginalis & 1 & - \\
\hline & Tubal tumor & - & 1 \\
\hline Immune system disorders & Allergy & $1^{*}$ & 1 \\
\hline \multirow[t]{3}{*}{ Skin and subcutaneous tissue disorders } & Itching & 1 & 1 \\
\hline & Urticaria & 1 & 1 \\
\hline & Herpes labialis & - & 1 \\
\hline \multirow[t]{3}{*}{ General disorders } & Intolerance & 1 & - \\
\hline & Weakness & 1 & - \\
\hline & Fever & 1 & - \\
\hline \multirow[t]{3}{*}{ Musculoskeletal, connective tissue and bone disorders } & Back pain & - & 1 \\
\hline & Flank pain & - & 2 \\
\hline & Leg pain & - & 1 \\
\hline
\end{tabular}

${ }^{\#}$ comparison of nitroxoline vs. controls (logistic regression with random center effect) $p=0.360$; *with papules/pustules. 
Table 12 Laboratory parameters before and after treatment in the safety-set

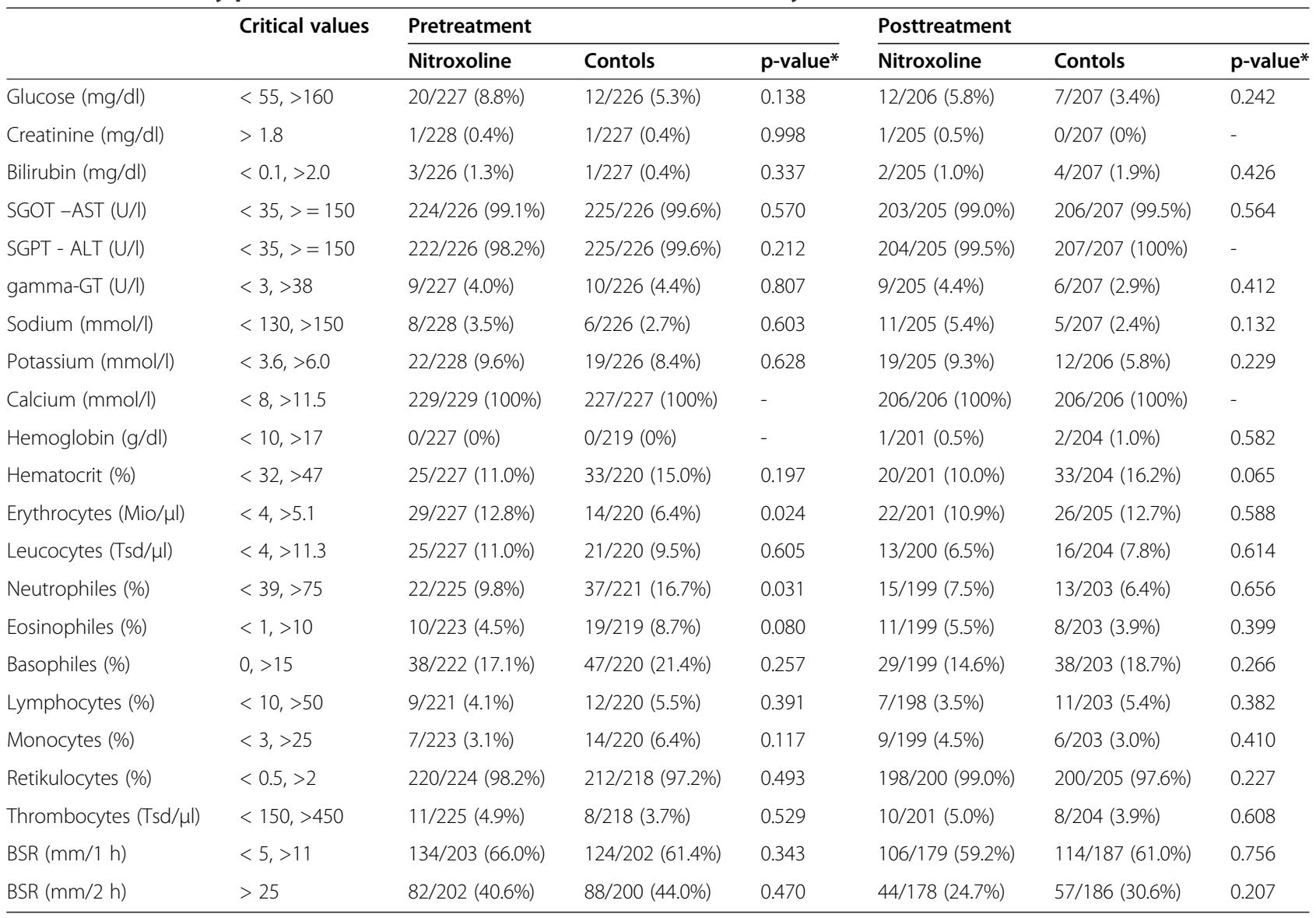

BSR-blood sedimentation rate.

*comparison of nitroxoline vs. controls, logistic regression with random center effect.

a modified PP set was evaluated, in which all patients dropping out before test of cure were considered treatment failure (worst case scenario). Only if the same results can be achieved in all three evaluation sets, the overall result (non-inferiority) can be taken as proven, which was established by this IPD meta-analysis for nitroxoline as compared to the controls.

The current guidelines do usually not recommend a longer treatment duration of an acute episode in women with recurrent UTI than in those with sporadic UTI any more. For cotrimoxazole and fluoroquinolones even a 3-day therapy is considered sufficient in acute uncomplicated cystitis, but for the usage of macrocrystal nitrofurantoin also a 5-day therapy is recommended in the current guidelines [11-13]. Therefore a 5-day therapy of nitroxoline $250 \mathrm{mg}$ tid should also be recommended as one of the first line options for the treatment of acute uncomplicated UTI (cystitis). Since about half of the female patients were pre- and postmenopausal in the studies meta-analysed, the dosage regimen and duration for both female groups can be considered the same, because in current guidelines an acute cystitis in otherwise healthy postmenopausal women is also considered as uncomplicated [12].

\section{Conclusions}

Nitroxoline used for more than 50 years for the treatment and prophylaxis of adult patients and children suffering from UTI has shown good clinical efficacy and safety as published in 26 uncontrolled, in two earlier controlled and in one large postmarketing observational study including a total of more than 11,000 patients. This first IPD meta-analysis of four so far unpublished, prospective, randomized, comparative clinical studies with a total of 466 female patients with sporadic or recurrent uncomplicated UTI has demonstrated non-inferiority $(10 \%$ non-inferiority margin) between treatment with nitroxoline versus controls (cotrimoxazole, norfloxacin). With a 5-day (sporadic UTI) and 10-day (recurrent UTI) treatment with nitroxoline $250 \mathrm{mg}$ t.i.d. eradication of bacteriuria could be achieved in over $90 \%$ of the patients. The safety of nitroxoline was comparable with that of the controls. Adverse events, mainly gastrointestinal disorders and only a few allergic reactions, were reported only in $9.4 \%$ patients 
treated with nitroxoline and $7.8 \%$ with the control drugs. Combining the vast clinical experience obtained from studies published earlier and non-inferiority of bacteriological efficacy with nitroxoline versus the controls as documented by this high quality IPD meta-analysis and considering the world wide increase of resistance of uropathogens against cotrimoxazole and fluoroquinolones, which has not been seen with nitroxoline despite clinical usage for more than 20 years, nitroxoline should be reconsidered as one of the first line antibiotics for the treatment of uncomplicated UTI.

\section{Abbreviations \\ CFU: Colony forming units; CRF: Clinical report form; CTX: Cotrimoxazole; IPD: Individual patients' data; MIC: Minimal inhibitory concentration; mMITT: Modified microbiological intention to treat; mPP: Modified per protocol; n: Number; NFX: Norfloxacin; NTX: Nitroxoline; P: Prophylaxis; PP: Per protocol; SMX: Sulphamethoxazole; T: Therapy; UTI: Urinary tract infection; CUTI: Complicated urinary tract infection; rUTI: Recurrent urinary tract infection; UUTI: Uncomplicated urinary tract infection.}

\section{Competing interests}

KGN has relations to Basilea (investigator, consultant), Bionorica (investigator, consultant, speakers bureau, scientific publication), Boehringer Ingelheim (consultant), Cubist (consultant), DaiichiSankyo (speakers bureau, scientific publication), Dr. Reddy's (speakers bureau), Galenus (consultant), Leo Pharma (consultant, speakers bureau), MerLion (consultant, investigator, scientific publication), OM Pharma/Vifor (consultant, investigator, speakers bureau, scientific publication), Paratek (consultant), Pierre Fabre (consultant, scientific publication), Rempex Pharma (consultant), Rosen Pharma (consultant, investigator, scientific publication), Shionogi (consultant), Zambon (consultant, investigator, speakers bureau, scientific publication). HN has relations to Rosen Pharma (statistical consultant, data analysis). GiS is employee of Rosen Pharma, Blieskastel, Germany. GuS has no company relations.

\section{Authors' contributions}

GiS had the idea for the literature review and meta-analysis and performed the narrative literature search. KGN, GiS and HN developed the plan for the IPD meta-analysis. Data analysis was performed by HN. KGN was mainly responsible for the data presentation and the manuscript assisted by the other authors. GuS supervised the project and contributed to the manuscript as well. All authors read and approved the final manuscript.

\section{Authors' information}

1. Assoc. Professor of Urology of the Technical University Munich, Munich; priv. address: Karl-Bickleder-Str. 44c, 94315 Straubing, Germany, e-mail: kurt@nabers.de; 2. Statistical Consulting \& Data Analysis, Schlehendornweg 24, 07751 Jena, Germany, e-mail: niggemann@p-wert.de; 3. Rosen Pharma, Kirkeler Str.41, 66440 Blieskastel-Niederwürzbach, Germany, e-mail: gisela.stein@rosen-pharma.de; 4. Em. Professor of Internal Medicine of the University of Jena; priv. address: Von-Hase-Weg 22, 07743 Jena, Germany, e-mail: guenter. stein@med.uni-jena.de

\section{Acknowledgements}

The study was supported by Rosen Pharma GmbH, St. Ingbert, Germany. Andrea Pfeiffer, Markus Prasser, and Walter Wittershagen extracted the data from the individual patient's CRFs into the statistical data management files.

\section{Author details}

${ }^{1}$ Department of Urology, Technical University of Munich, Ismaningerstr. 22, 81675 Munich, Germany. ${ }^{2}$ Statistical Consulting \& Data Analysis,

Schlehendornweg 24, 07751 Jena, Germany. ${ }^{3}$ Rosen Pharma, Kirkeler Str.41, 66440 Blieskastel, Germany. ${ }^{4}$ Department of Internal Medicine, University of Jena, Erlanger Allee 101, 07747 Jena, Germany.

Received: 2 March 2014 Accepted: 10 November 2014

Published online: 27 November 2014

\section{References}

1. Naber KG, Schito G, Botto H, Palou J, Mazzei T: Surveillance study in Europe and Brazil on clinical aspects and antimicrobial resistance epidemiology in females with cystitis (ARESC): implications for empiric therapy. Eur Urol 2008, 54:1164-1178.

2. Kahlmeter G: The ECO-Sens Projekt: a prospective, multicentre epidemiological survey of the prevalence and antimicrobial susceptibility of urinary tract pathogens- interim report. J Antimicr Chem 2000, 46:15-22.

3. Kahlmeter G, Odén Poulsen H: Antimicrobial susceptibility of Escherichia coli from community-acquired urinary tract infections in Europe: the ECO.SENS study revisited. Int J Antimicr Agents 2012, 39:45-51.

4. Wagenlehner FME, Naber KG: Emergence of antibiotic resistance and prudent use of antibiotic therapy in nosocomially acquired urinary tract infections. Int J Antimicr Agents 2004, 23:24-29.

5. Fisher JF, Newman CL, Sobel JD: Yeast in the urine: solutions for a budding problem. Clin Infect Dis 1995, 20:183-189.

6. Bukhary ZA: Candiduria: a review of clinical significance and management. Saudi J Kidney Dis Transpl 2008, 19:350-360.

7. Azap OK, Arslan H, Serefhanoglu K, Colakoglu S, Erdogan H, Timurkaynak F, Senger SS: Risk factors for extended-spectrum b-lactamase positivity in uropathogenic Escherichia coli isolated from community-acquired urinary tract infections. Clin Microbiol Infect 2010, 16:147-151.

8. Lee S-J, Lee DS, Choe HS, Shim BS, Kim CS, Kim ME, Cho Y-H: Antimicrobial resistance in community-acquired urinary tract infections: results from the Korean antimicrobial resistance monitoring system. J Infect Chemother 2011, 17:440-446.

9. Tandogdu Z, Cek M, Wagenlehner F, Naber K, Tenke P, van Ostrum E, Bjerklund Johansen $\mathrm{T}$ : Resistance patterns of nosocomial urinary tract infections in urology departments: 8-year results of the global prevalence of infections in urology study. World J Urol 2013, 32:791-801.

10. Warren JW, Abrutyn E, Hebel JR, Johnson JR, Schaeffer AJ, Stamm WE: Guidelines for antimicrobial treatment of uncomplicated acute bacterial cystitis and acute pyelonephritis in women. Clin Infect Dis 1999, 29:745-758

11. Gupta K, Hooton TM, Naber KG, Wullt B, Colgan R, Miller LG, Moran GJ, Nicolle LE, Raz R, Schaeffer AJ, Soper DE: International clinical practice guidelines for the treatment of acute uncomplicated cystitis and pyelonephritis in women: a 2010 update by the Infectious Diseases Society of America and the European Society for Microbiology and Infectious Diseases. Clin Infect Dis 2011, 52:103-120.

12. Wagenlehner FME, Schmiemann G, Hoyme U, Fuenfstueck R, Hummers-Pradier E, Kaase M, Kniehl E, Selbach I, Sester U, Vahlensieck W, Watermann D, Naber KG: Epidmiology, diagnostics, therapy and management of uncomplicated bacterial community acquired urinary tract infections in adults. [http:// www.awmf.org/uploads/tx_szleitlinien/043-044l_S3_Harnwegsinfektionen.pdf] (visited 16 Nov 2014)

13. Grabe M, Bjerklund Johansen TE, Botto H, Wullt B, Cek M, Naber KG, Pickard RS, Tenke P, Wagenlehner F: Guidelines on Urological Infections. Part 19. Arnhem, The Netherlands: European Association of Urology; 2014:1-107. ISBN 978-90-79754-65-6 [http://www.uroweb.org/gls/pdf/19\%20Urological\% 20infections_LR.pdf] (visited 16 Nov 2014).

14. Kleemann A, Engel J, Reichert D, Kutscher B: Pharmaceutical Substances. Syntheses, Patents Applications. Stuttgart, New York: Thieme; 1999:1355-1356.

15. Sweetman SC: Martindale. The Complete Drug Reference. 34th edition. London: Pharmaceutical Press; 2004:238.

16. Rosen Pharma: Summary of Product Characteristics (SPC) of Nitroxolin Forte [Article in German]. [http://www.fachinfo.de/suche/fi/009370] (visited 16 Nov 2014)

17. Jacobs MR, Robinson RG, Koornhof HJ: Antibacterial activity of nitroxoline and sulphamethizole alone and in combination in urinary tract infections. S Afr Med J 1978, 54:959-962

18. Bourlioux P, Amgar A: Multicenter study of the resistance to seven antibiotics of pathogens recovered from urinary tract infections [Article in French]. Sem Hôp Paris 1988, 64:86-90.

19. National Antibiotic Susceptibility Testing Committee (Germany): Nitroxoline. Rationale for the NAK Clinical Breakpoints. [http://www.nak-deutschland. org/tl_files/nak-deutschland/Nitroxoline_rationale_V_1.0_31012014.pdf] (visited 16 Nov 2014).

20. Bonissol C, Pua K, Stoiljkovic B: In vitro activity of nitroxoline on urogenital mycoplasmas [Article in French]. Pathol Biol (Paris) 1966, 34:1001-1005. 
21. Amgar A: Activity in vitro of urine samples from patients treated by nitroxoline against mycoplasmas. J Chemother 1989, 4:226-228.

22. Hernández Molina JM, Llosá J, Ventosa A: In vitro activity of nitroxoline against clinical isolates of Candida species. Mycoses 1991, 34:823-825

23. Focht J, Noesner K: In-vitro activity of nitroxoline against Candida [Article in German]. Extracta Urologica 1995, 18:26-27.

24. Lambert-Zechovsky N, Leveque B, Bingen E, Pillion G, Chapelle J, Mathieu H: Clinical study and effect of nitroxoline on fecal flora in children [Article in French]. Pathol Biol (Paris) 1987, 35:669-672.

25. Kresken M, Körber-Irrgang B, on behalf of the Working Party Antimicrobial Resistance of the Paul Ehrlich Society of Chemotherapy: In vitro activity of nitroxoline against urine isolates of Escherichia coli from the community: results of a German multicentre study [Abstract]. In 23rd European Congress of Clinical Microbiology and Infectious Diseases (23rd ECCMID): 27-30 April 2013; Berlin, Germany. [http://registration.akm.ch/einsicht.php? XNABSTRACT_ID $=160328 \& X N S P R A C H E \_I D=2 \& X N K O N G R E S S$ ID $=$ 180\&XNMASKEN_ID=900] (visited 16 Nov 2014)

26. Kresken $M$, Körber-Irrgang $B$ : In vitro activity of nitroxoline against uropathogens other than Escherichia coli and impact of pH [Poster]. In 24th European Congress of Clinical Microbiology and Infectious Diseases (24th ECCMID): 10-13 May 2014; Barcelona, Spain.

27. Cancet $B$, Amgar A: In vitro antifungal activity of nitroxoline. Preliminary clinical results [Article in French]. Pathol Biol (Paris) 1987, 35:879-881.

28. Michel-Nguyen A, Nourrit J, Penaud A, Nicoli RM: Nitroxoline and traditional antifungal agents. Comparison of their antifungal activity against 238 yeast strains [Article in French]. Bull Soc Fr Mycol Med 1986, 15:265-268.

29. Bourlioux P, Karam D, Amgar A, Perdiz M: Relationship between the chelating activity of nitroxoline, bacterial surface hydrophobicity and the reduction of bacterial adherence [Article in French]. Pathol Biol (Paris) 1989, 37:600-604.

30. Pelletier C, Prognon P, Latrache $H$, Villart L, Bourlioux P: Microbiological effects of divalent metal ions interaction with nitroxoline [Article in French]. Pathol Biol (Paris) 1994, 42:406-411.

31. Pelletier $C$, Prognon $\mathrm{P}$, Bourlioux $\mathrm{P}$ : Roles of divalent cations and $\mathrm{pH}$ in mechanism of action of nitroxoline against Escherichia coli strains. Antimicrob Agents Chemother 1995, 39:707-713.

32. Latrache $H$, Bourlioux P, Karroua M, Zahir H, Hakkou A: Effects of subinhibitory concentrations of nitroxoline on the surface properties of Escherichia coli. Folia Microbiol 2000, 45:485-490.

33. Fraser RSS, Creanor J: Rapid and selective inhibition of RNA synthesis in yeast by 8-hydroxyquinoline. Eur J Biochem 1974, 46:67-73.

34. Karam D, Amgar A, Bourlioux P: Inhibition of bacterial adherence from uropathogenic Escherichia coli strains by the urine of patients treated by nitroxoline [Article in French]. Pathol Biol (Paris) 1988, 36:452-455

35. Bourlioux P, Botto H, Karam D, Amgar A, Camey M: Reduction of bacterial adherence by nitroxoline on epithelial cells and on urinary catheter surfaces [Article in French]. Pathol Biol (Paris) 1889, 37:451-454.

36. Oliviero L, Perdiz M, Bourlioux P: Direct effect of nitroxoline in the reduction of bacterial adherence on urinary catheter [Article in French]. Pathol Biol (Paris) 1990, 38:455-458.

37. Sobke A, Klinger M, Hermann B, Sachse S, Nietzsche S, Makarewicz O, Keller PM, Straube PW: The urinary antibiotic 5-nitro-8-hydroxyquinoline (nitroxoline) reduces the formation and induces the dispersal of Pseudomonas aeruginosa biofilms by chelation of iron and zinc. Antimicrob Agents Chemother 2012, 56:6021-6025.

38. Bergogne-Berezin E, Berthelot G, Muller-Serieys C: Present status of nitroxoline [Article in French]. Pathol Biol (Paris) 1987, 35:873-878.

39. Mrhar A, Kopitar Z, Kozjek F, Presl V, Karba R: Clinical pharmacokinetics of nitroxoline. Int J Clin Pharmacol Biopharm 1979, 17:476-481.

40. Wagenlehner FME, Münch F, Pilatz A, Bärmann B, Weidner W, Wagenlehner CM, Straubinger M, Blenk H, Pfister W, Naber KG: Urinary antibacterial activity of Nitroxoline $250 \mathrm{mg}$ and Trimethoprim $200 \mathrm{mg}$ against uropathogens in healthy volunteers. Antimicrob Agents Chemother 2014, 58:713-721.

41. Sorel RH, Snelleman C, Hulshoff A: High-performance liquid chromatographic analysis of nitoxoline in plasma and urine. J Chromatogr 1981, 222:241-248.

42. Franz $M$ : The treatment of urinary tract infections with nitroxoline [Article in German]. Z Allg Med 1992, 68:526-530.
43. Kuss R, Rometti A: Efficacy of 5-nitro-8-hydroxyquinoline (A82) in urinary tract infections [Article in French]. Extrait de la Presse Médicale 1962, 23:1131-1132

44. Moreau L, Reveillaud R-J: A new urinary antifungal antibiotic [Article in French]. Essais Cliniques Du A. 82. Extrait de la Vie Médicale 1962, 43:35

45. von Rütte B, Delnon I: Experiences with drugs. Chronic urinary tract infection and its treatment with Nibiol [Article in German]. Schweiz Med Wochenschr 1968, 47(98):1864-1868.

46. Uhlir O, Hnatek J, Hatala M: Laboratory and clinical evaluation of 5-NOK. In Advances in Antimicrobial and Antineoplastic Chemotherapy. Progress in Research and Clinical Application, Proceedings of the Vllth International Congress of Chemotherapy, Prague, 1971. Volume I/1 Antimicrobial Chemotherapy I. Urban \& Schwarzenberg, Munich, Berlin, Vienna. Edited by Hejzlar M, Semonský M, Masák S; 1972:1353-1354.

47. Allal A, Giraud J-R, Kamina P, de Tourris H: Contribution to the treatment of urinary tract infections in pregnancy [Article in French]. L'Ouest Médical 1973, 4:439-444.

48. Bittard M, Colas J-M, Henry J-C: Current value of nitroxyquinoline in the treatment of urological infections [Article in French]. J de Besançon 1974, 10(3):183-188.

49. Schlesinger $E$, Patsch $R$, Kraft M: Initial experience with 5-nitrooxyquinoline in the treatment of chronic urinary tract infection [Article in German]. Zschr Urolog 1975, 68(6):429-434.

50. Aubert J: Significance of anti-bacterial prevention with Nibiol forte during urological instrumentations [Article in French]. Ouest Médical 1976, 29(23):1762-1765.

51. Dufour A, Bollack C: Penetration of nitroxoline into prostatic tissuea. A therapeutic trial [Article in French]. J Urol Nephrol 1979, 3:207-212.

52. Lenzner A: Oral treatment with nitroxoline for fungal complaints of urinary tract [Article in German]. Therapie Woche 1983, 33:1735-1738.

53. Schülke J, Sökeland J: Treatment of post operative urinary tract infection with Nitroxoline [Article in German]. Prakt Arzt 1984, 21(25):1692-1696.

54. Sachse D: Therapy for chronically-recurrent urinary tract infection with nitroxoline [Article in German]. Therapie Woche 1984, 34:228-230.

55. Demontrond D, Steinmetz P, Bernard PF: Treatment of 15 patients with nitroxoline for fungal urinary tract infections [Article in French]. Bull Soc Fr Mycol Med 1986, XV(2):307-310.

56. Frobert $J \mathrm{~L}$, Coupry A: Nibiol forte in the treatment of uncomplicated lower urinary tract infections in women [Article in French]. Gazette Médicale 1987, 94(17):71-74.

57. Lecornu M: The use of a suspension of nitroxoline for the treatment of pediatric urinary tract infections [Article in French]. Ouest Médical 1974, 7:715-717.

58. Roussel B, Dupouy D, Couchot J, Gomes H, Fandre M: Value of Nibiol suspension in the treatment of urinary tract infection in the infant and the child [Article in French]. J des Médecins du Nord de l'Est 1974, 2:85-87.

59. Raynaud: Nibiol suspension in pediatrics [Article in French]. Médecine Practicienne 1974, 567:59-60.

60. Luckel JC, Brochard A, Juif JG: Value of Nibiol suspension in urinary tract infections in children [Article in French]. J Méd Strasbourg 1975, 6:545-548.

61. Viville C: Clinical trial of nitroxoline suspension [Article in French]. Méd Gén Med Nord 1975, 1:63-65.

62. Chable JP, Dumas R, Jean R: Nitroxoline in treatment of urinary tract infections in children [Article in French]. Bord Med 1975, 3:305-313.

63. Battin J: Use of nibiol suspension (nitroxoline) in pediatrics [Article in French]. Bord Med 1975, 13:1597-1600.

64. Sorez J, Vanlaeys R, Lelong M: Influence of a suspension of nitroxoline (Nibiol) in childhood urinary tract infections [Article in French]. Med Gen Med Nord 1975, 2:49-53.

65. Neimann N, Andre JL: Clinical trial of Nibiol (nitroxoline) suspension in urinary infections in the infant and child [Article in French]. Med Gen Med Nord 1975, 1:90-96.

66. Machecourt D, Lebranchu Y, Bost M: Nitroxoline in treatment of urinary infections in children [Article in French]. RMAF 1976, 9:347-351.

67. Schülke J: Are gyrase inhibitors always better? [Article in German]. Therapie Woche 1986, 36(42):4294-4297.

68. Dodat $H$, Chavrier $Y$, Dyon JF, Aubert D, Galifer RB, Montupet $P$, Morisson-Lacombe G, Moscovici J, Valla J: Multicenter clinical study of nitroxoline versus cotrimoxazole for prevention of urinary tract infection in children [Article in French]. Gazette Médicale 1988, 95(29):56-59. 
69. WMA Declaration of Helsinki: Ethical principles for medical research involving human subjects. Adopted by the 18th WMA General Assembly, Helsinki, Finland, June 1964, and amended by the 41st WMA General Assembly, Hong Kong, September 1989. http://www.wma.net/en/30publications/ 10policies/b3/index.html.pdf (visited 16 Nov 2014)

70. Naber KG: Experience with the new guidelines on evaluation of new anti-infective drugs for the treatment of urinary tract infections. Int $J$ Antimicrob Agents 1999, 11:189-196. discussion 213-216.

71. Piaggio G, Elbourne DR, Altman DG, Pocock SJ, Evans SJ, for the CONSORT Group: Reporting of noninferiority and equivalence randomized trials. An extension of the CONSORT statement. JAMA 2006, 295:1152-1160.

72. Rabe-Hesketh S, Skrondal A: Multilevel and Longitudinal Modeling Using Stata. 3rd edition. College Station, TX: Stata Press; 2012.

73. Jadad AR, Moore RA, Carroll D, Jenkinson C, Reynolds JM, Gavaghan DJ, McQuay HJ: Assessing the quality of reports of randomized clinical studies: is blinding necessary? Contr Clin Trials 1996, 17:1-12.

74. Abraham NS, Moayyedi P, Daniels B, van Zanten JO: Systematic review: the methodological quality of trials affects estimates of treatment efficacy in functional (non-ulcer) dyspepsia. Aliment Pharmacol Ther 2004, 19:631.

75. Cochrane Individual Participant Data (IPD) Meta-analysis Methods Group: About IPD meta-analyses. [http://ipdmamg.cochrane.org/about-ipd-meta-analyses] (visited 16 Nov 2014)

76. Stewart LA, Tierney JF: To IPD or not to IPD? Advantages and disadvantages of systematic reviews using individual patient data. Eval Health Prof 2002, 25:76-97.

doi:10.1186/s12879-014-0628-7

Cite this article as: Naber et al:: Review of the literature and individual patients' data meta-analysis on efficacy and tolerance of nitroxoline in the treatment of uncomplicated urinary tract infections. BMC Infectious

Diseases 2014 14:628

\section{Submit your next manuscript to BioMed Central and take full advantage of:}

- Convenient online submission

- Thorough peer review

- No space constraints or color figure charges

- Immediate publication on acceptance

- Inclusion in PubMed, CAS, Scopus and Google Scholar

- Research which is freely available for redistribution 